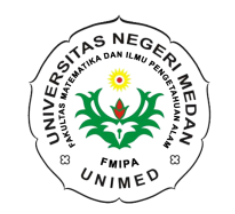

\author{
JURNAL EINSTEIN \\ Jurnal Hasil Penelitian Bindang Fisika \\ Available online http://jurnal.unimed.ac.id/2012/index.php/einsten \\ e-issn: $2407-747 x$, p-issn $2338-1981$
}

\title{
DYE SENSITIZED SOLAR CELL (DSSC) MENGGUNAKAN FILM TIPIS ZNO:B DAN EKSTRAK DYE DARI UBI UNGU
}

\author{
Nurdin Siregar, Nurhabibah Purba dan Motlan \\ Jurusan Fisika, Fakultas Matematika dan Ilmu Pengetahuan Alam, Universitas Negeri Medan, \\ Indonesia \\ habibahpurba@gmail.com \\ Diterima Februari 2018; Disetujui Februari 2018; Dipublikasikan Februari 2018
}

\begin{abstract}
ABSTRAK
Prototype DSSCdoping boron 2,5\% telah berhasil disintetis dengan metode sol-gel spin coating. Penelitian mengenai dye sensitized solar cell (DSSC) dilakukan dengan menggunakan dye dari ekstrak ubi ungu, larutan elektrolit mosalyte dan elektroda lawan berupa platina. Elektrode kerja yaitu $\mathrm{ZnO}$ doping boron yang dideposisikan pada kaca konduktif ITO (Indium Tin Oxide). Variasi konsentrasi doping adalah $2.5 \%$ dengan menggunakan boron lemah yaitu boric acid (H3BO3). Lapisan film tipis ZnO:B dikarakterisasi dengan menggunakan SEM, XRD, UVVis Spektrometer, dan FTIR. Berdasarkan karakterisasi UV-Vis, diperoleh nilai absorbansi larutan dye ubi ungu adalah 0,67 a.u pada panjang gelombang $515 \mathrm{~nm}$. Nilai energi gap dari film tipis ZnO:B 2,5\% adalah 3,161 eV. Nilai ukuran kristal yang diperoleh yaitu $29 \mathrm{~nm}$. Efisiensi DSSC pada konsentrasi doping boron 2,5\% adalah sebesar 0,118\%.
\end{abstract}

Kata Kunci : Dye Sensitized Solar Cell, Boric acid, Indium Tin Oxide, Mosalyte, ZnO:B, Boron

\section{PENDAHULUAN}

Zinc Oksida merupakan semikonduktor tipe-n dengan lebar pita energi $3,37 \mathrm{eV}$ dan energi ikat sebesar $60 \mathrm{meV}$ sehingga memungkinkan penyerapan radiasi UV secara langsung (Fattah, 2016). ZnO adalah semikonduktor dengan celah pita lebar pada grup semikonduktor II-VI. Semikonduktor ini memiliki beberapa sifat yang menguntungkan, termasuk transparansi yang baik, dan mobilitas elektron yang tinggi. $\mathrm{ZnO}$ diakui sebagai salah satu material lapisan tipis yang paling menjanjikan karena mempunyai sifat optik, listrik dan piezoelectric yang baik.

Film tipis $\mathrm{ZnO}$ selalu menarik perhatian para peneliti untuk dipelajari sifat optik, sifat kelistrikannya dan pengaplikasiannya. Sifat optik dari film tipis berbasis sol-gel tergantung pada beberapa faktor seperti metode persiapan, bahan prekursor dan substrat, cara pemanasan prekursor, dll. Alternatifnya, film tipis dapat disesuaikan dengan penambahan doping kimia ke dalam prekursor padatan/cairan terutama dengan unsur-unsur kelompok IIIA misalnya B, Al, dan Ga (Jana, dkk. 2011). Di antara dopan tersebut, doping Boron bisa sangat efektif untuk menyesuaikan film tipis karena unsur tersebut memiliki jari-jari ionik terendah $\left(\mathrm{r}_{\mathrm{R}}\right)$, muatan nuklir efektif tertinggi (Z), memiliki nilai yang tinggi untuk $\mathrm{Z} / \mathrm{rR}^{2} \quad(17,85)$ yang akan mempolarisasi elektron lebih kuat dari oksigen (Wen, dkk. 2017). Karena jari-jari ion boron yang kecil $\left(0,23 \mathrm{~A}^{0}\right)$, boron dapat bertindak sebagai boron interstisial yaitu sebagai pensubstitusi kedalam kisi ZnO. Selain itu, 
boron memiliki nilai elektronegativitas tertinggi yaitu 2,04 (Karakaya dan Ozbas, 2014).

Pada penelitian sebelumnya film tipis $\mathrm{ZnO}: \mathrm{B}$ telah dideposisi dengan menggunakan metode spray pyrolysis demgan variasi konsentrasi doping boron (Rahman, 2016). Wen, 2016 telah melakukan deposisi film tipis $\mathrm{ZnO}: \mathrm{B}$ dengan metode sol-gel spin ngan variasi konsentrasi doping boron yang berbeda.

Pada penelitian ini metode yang digunakan pada saat sintetis film tipis $\mathrm{ZnO}: \mathrm{B}$ adalah metode sol-gel spin coating yang dideposisi di atas kaca ITO (Indium Tin Oxide). Variasi konsentrasi doping boron yang digunakan adalah 2,5\%. Larutan dye yang digunakan adalah ekstrak ubi ungu.

\section{METODE PENLITIAN}

Penelitian ini di lakukan di Laboratorium Biologi UNIMED dan Laboratorium Fisika Material UNPAD. ZnO:B dideposisi di atas kaca ITO dengan metode solgel spin coating. Bahan penelitian yang digunakan adalah Zinc Acetat Dehydrate (MERCK), Boric Acid ( $\left.\mathrm{H}_{3} \mathrm{BO}_{3}\right)$ (MERCK), Isopropanol sebagai pelarut dan Diethanolamine sebagai stabilizer.

Sintetis $\mathrm{ZnO}$ dengan konsentrasi doping Boron (B) 2,5\%, sebanyak 3,98 gram Zinc Acetat dehydrate $\left\{\mathrm{Zn}\left(\mathrm{CH}_{3} \mathrm{COOH}\right) \cdot 2 \mathrm{H}_{2} \mathrm{O}\right\}$ dan 0,1 gram Boron (B) dilarutkan kedalam 35,47 $\mathrm{ml}$ sampel isopropanol. Selanjutnya distirrer dengan kecepatan $250 \mathrm{rpm}$ pada suhu 6085C.Setelah 10 menit kemudian dimasukkan sedikit demi sedikit $1,72 \mathrm{ml}$ Diethanolamine (DEA) ke dalam sampel secara perlahan-lahan dan tunggu hingga warna larutan berwarna putih bening. Hasil sintetis $\mathrm{ZnO}: \mathrm{B}$ dideposisi di substrat dengan spin coating. Film tipis yang terbentuk di pre-heating dengan suhu $250^{\circ} \mathrm{C}$ selama 5 jam kemudian di post-heating selama 5 jam.

Morfologi film tipis $\mathrm{ZnO} \mathrm{B}$ diperoleh dengan karakterisasi SEM ZEISS EVO. Sifat optik film tipis dan larutan $d y e$ diperoleh melalui karakterisasi UV-Vis Spektrometer, struktur kristal film tipis diperoleh dari hasil karakterisasi $X$-ray Diffraction (XRD) model 6100 SHIMADZU dan hasil pengukuran dengan infra red diperoleh dari hasil uji FTIR Perkin Elmer Tipe 1.

\section{Sintetis Larutan Dye}

Sintetis larutan dye dilakukan dengan menyiapkan bahan yang menjadi kandidat untuk dye. Bahan tersebut yakni ubi jalar ungu sebanyak 40 gram. Bahan tersebut diekstraksi dengan cara diletakkan dalam beaker glass kemudian dipotong kecil-kecil dan digerus dengan mortar hingga merata. Setelah itu, ekstrak dilarutkan dengan menambahkan $16 \mathrm{ml}$ aquadest, $30 \mathrm{ml}$ methanol, dan $4 \mathrm{ml}$ asam asetat. Kemudian direndam selama 24 jam di tempat yang gelap. Selanjutnya ekstrak disaring menggunakan kertas saring dan dimasukkan dalam wadah yang telah dilapisi dengan aluminium foil dan disimpan di tempat yang gelap untuk menghindari hasil ekstrak terkena sinar (cahaya).

\section{Perakitan DSSC}

Kaca konduktif ITO dengan lapisan oksida $\mathrm{ZnO}$ :B yang sudah dicelupkan ke dalam sampel $d y e$ yang berperan sebagai elektroda kerja, dan counter electroda platina ditempel dengan lapisan pemisah surilyn.Penempelan dengan surilyn dilakukan dengan cara menekan elektroda kerja dan elektroda lawan dan dipanaskan pada hot plate dengan suhu $70-80^{\circ}$ agar surilyn menempel dengan sempurna. Kemudian elektroda kerja yang telah ditempel dengan elektroda lawan berupa platina, diinjeksi dengan larutan elektrolit cair melalui lubang kecil yang terdapat pada elektrode lawan platina.

\section{HASIL DAN PEMBAHASAN}

\subsection{Struktur Kristal Film Tipis ZnO:B}

Gambar 1. menunjukkan hasil XRD sampel film tipis $\mathrm{ZnO}: \mathrm{B}$ 2,5\%. Untuk kristal ZnO:B 2,5\% puncak pertumbuhan terorientasi pada bidang (100)berbentuk hexagonal pada $2 \theta=32,3139$, bidang (002) pada $2 \theta=$ $35,0955^{\circ}$ dan bidang (101) pada $2 \theta=36,7915^{\circ}$. Hasil penelitian ini sesuai dengan penelitian Yi Lee, dkk.(2012) bahwa semua variasi sampel berbentuk hexagonal dan puncak kristal terorientasi pada bidang (002). 


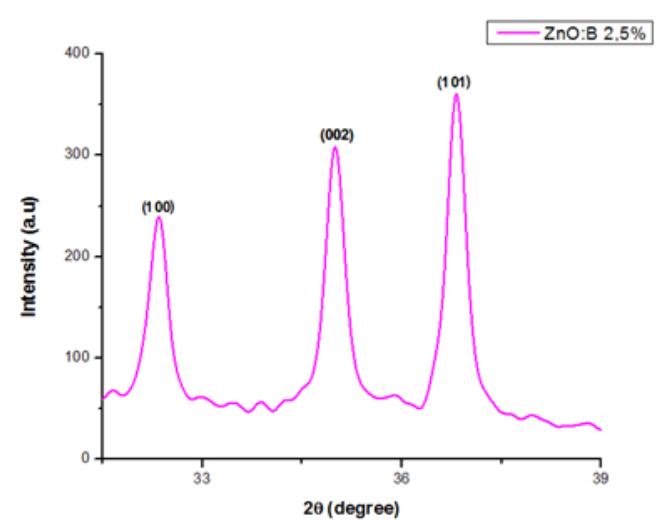

Gambar 1. Grafik XRD dari ZnO:B 2,5\%

Besar ukuran kristal diukur berdasarkan grafik hasil XRD dengan cara mengambil nilai puncak (peak) tertinggi. Pada sampel film tipis $\mathrm{ZnO}: \mathrm{B}$ 2,5\% ukuran kristal yang diperoleh adalah $29 \mathrm{~nm}$.

\subsection{Sifat Optik Film Tipis ZnO:B}

Gambar 2. menunjukkan grafik absorbansi $\mathrm{ZnO}: \mathrm{B} \quad 2,5 \%$ dimana panjang gelombang yang muncul berada pada daerah ultraviolet yaitu pada kisaran $350-400 \mathrm{~nm}$. Hasil ini hampir sama dengan Rahman, dkk.(2015) yang memperoleh spektrum di daerah penyerapan ultra violet dengan panjang gelombang $320 \mathrm{~nm}-370 \mathrm{~nm}$.

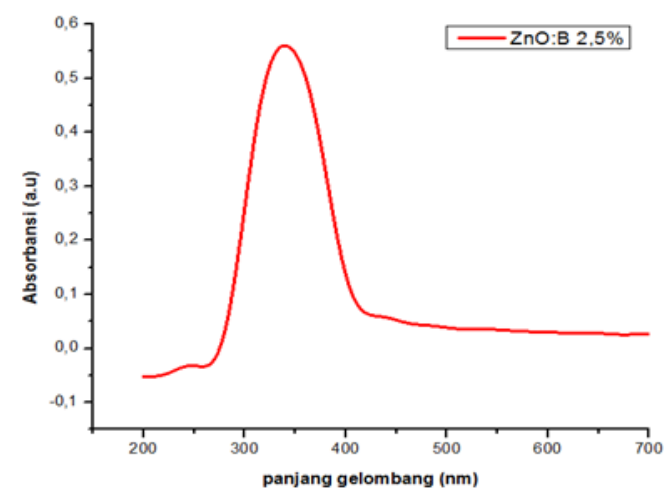

Gambar 2. Grafik absorbansi ZnO:B 2,5\%

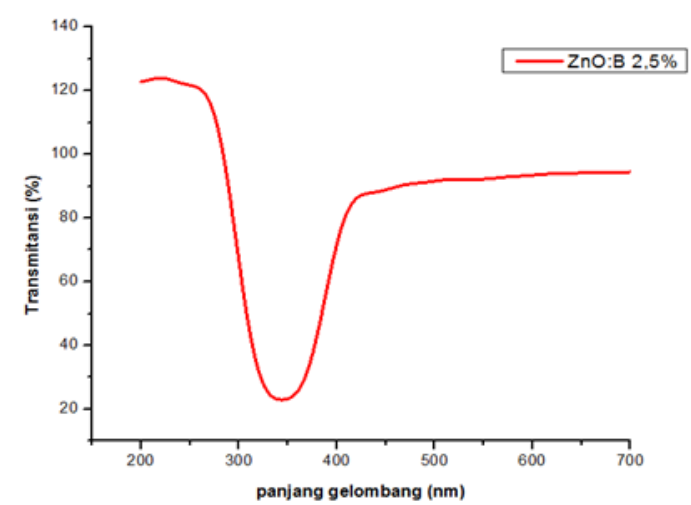

Gambar 2. Grafik transmitansi ZnO:B 2,5\%
Gambar 3. menunjukkan grafik transmitansi $\mathrm{ZnO}: \mathrm{B} \quad 2,5 \%$ dimana panjang gelombang maksimum yang terbentuk berada pada daerah sinar tampak sedangkan panjang gelombang minimum berada pada daerah ultraviolet.Nilai transmitansi yang cukup tajam terjadi pada rentang $350-400 \mathrm{~nm}$ dimana pada rentang $>400 \mathrm{~nm}$ nilai transmitansi cukup stabil. Hasil ini hampir sama dengan yang diperoleh Kim, dkk. (2013) dengan nilai transmitansi berada diantar rentang 360-400 $\mathrm{nm}$ dan cukup stabil di rentang $>400 \mathrm{~nm}$. Nilai transmitansi dapat dipengaruhi oleh beberapa faktor, antara lain jumlah atom doping yang masuk kedalam kisi $\mathrm{ZnO}$, ukuran butir kristal, permukaan lapisan bertekstur, kekasaran permukaan, pembentukan senyawa lain yang tumbuh pada waktu yang sama dengan lapisan $\mathrm{ZnO}$ doping, dan kerapatan lapisan pada film tipis (Purwaningsih, dkk. 2005).

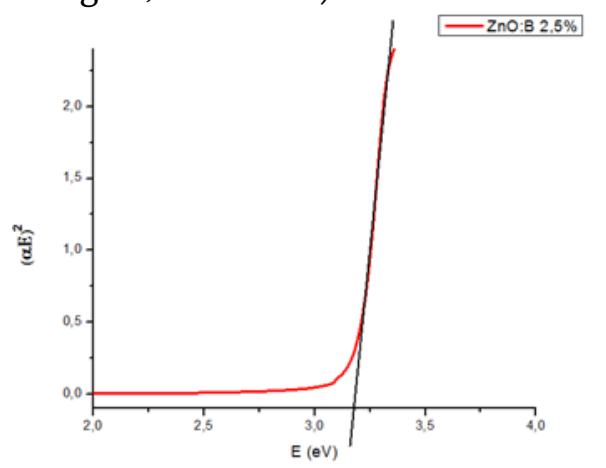

Gambar 4. Nilai energi gap ZnO:B 2,5\%

Gambar 4 menunjukkan nilai energi gap pada $\mathrm{ZnO}: \mathrm{B}$ 2,5\% dengan nilai $3,161 \mathrm{eV}$. Energi gap film tipis $\mathrm{ZnO}: \mathrm{B}$ 2,5\% dihitung menggunakan metode Tauc Plot dan diperoleh nilai E seperti yang terlihat pada Gambar 4 . Kenaikan energi gap pada film tipis $\mathrm{ZnO}: \mathrm{B}$ dipengaruhi oleh beberapa faktor, seperti permukaan yang tidak rata dari lapisan $\mathrm{ZnO}: \mathrm{B}$ yang dapat menyebabkan refleksi cahaya dengan sudut yang berbeda sehingga seolaholah terjadi penyerapan pada panjang gelombang sinar tampak dan dapat juga disebabkan oleh peristiwa Blue-Shift.

\subsection{UV-Vis Larutan Dye}




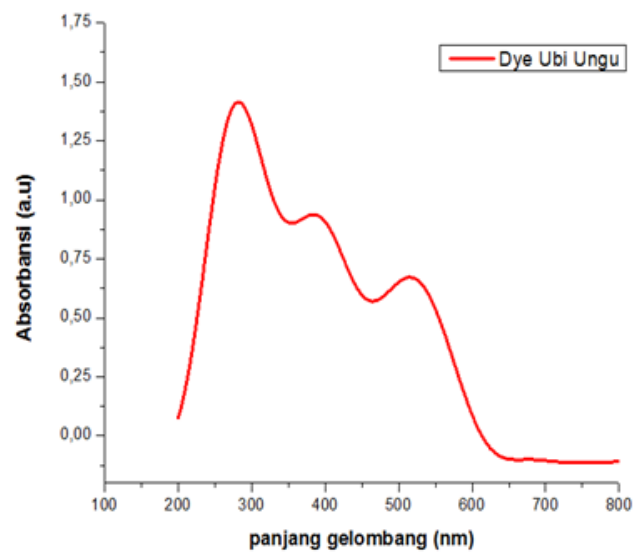

Gambar 5. Grafik hasil UV-Vis larutan dye ubi ungu

Gambar 5. menunjukkan grafik UV-Vis larutan dye ubi ungu. Dari hasil pengujian UVVIS di atas, diketahui bahwa nilai absorbansi larutan dye ubi ungu adalah 0,67 a.u sedangkan nilai panjang gelombangnya adalah $515 \mathrm{~nm}$. Hasil dari pengujian ini hampir mendekati seperti yang dilakukan Winarti, dkk. (2008) juga telah melakukan penelitian dan diperoleh nilai panjang gelombang maksimum dye ubi ungu $517 \mathrm{~nm}$ dan nilai absorbansi tertinggi adalah 0,6 a.u. Nilai absorbansi pada ekstrak ubi ungu yang tinggi ini menunjukkan tingginya konsentrasi larutan dye dalam menyerap radiasi energi yang diberikan.

\subsection{Efisiensi DSSC}

Elemen penting untuk mengetahui nilai efisiensi DSSC adalah tegangan dan kuat arus maksimal yang dihasilkan oleh DSSC. Kedua nilai tersebut dikalikan sehingga dihasilkan nilai daya terbesar $\left(\mathrm{P}_{\max }\right)$ dari DSSC tersebut. Persentase efisiensi dapat diperoleh dengan membandingan daya yang dihasilkan DSSC $\left(\mathrm{P}_{\max }\right)$ dengan daya yang masuk $\left(\mathrm{P}_{\mathrm{in}}\right)$.

Nilai efisiensi DSSC dengan konsentrasi doping boron 2,5\% adalah $0,118 \%$. Penelitian kali ini menghasilkan nilai efisiensi yang hampir sama dengan penelitiansebelumnya (Rahman, dkk. 2015) dengan menggunakan doping boron dan metode hydrothermal. yaitu sebesar 0,13\% pada konsentrasi doping boron 2,5\%.

\section{KESIMPULAN DAN SARAN}

Dye Sensitized Solar Cell (DSSC) dapat difabrikasi menggunakan semikonduktor $\mathrm{ZnO}$ (Zinc Oxide) dan dye dari ekstrak ubi ungu. Film tipis doping boron berhasil disintetis dengan menggunakan metode sol-gel spin coating. Hasil XRD menunjukkan struktur kristal berbentuk hexagonal. Sifat optik film tipis $\mathrm{ZnO}: \mathrm{B}$ berupa energi gap diperoleh nilai 3,161 eV. Efisiensi DSSC dengan konsentrasi doping boron 2,5\% adalah sebesar $0,118 \%$.

\section{DAFTAR PUSTAKA}

Fattah, Z.A. (2016). Synthesis and Characterization Of Nickel Doped Zinc Oxide Nanoparticles by Sol - Gel Method. International Journal Of Engineering Sciences \& Research Technology. 2277-9655.

Jana, S., Vuk, A.S., Mallick, A., Orel, B., Biswas, P.K., (2011).Effect of Boron Doping on Optical Properties of Sol-Gel Based Nanostructured Zinc Oxide Films on Glass. Materials Research Bulletin.(46) : 2392-2397.

Karakaya, S., and Ozbas, O., (2014). Boron Doped Nanostructure $\mathrm{ZnO}$ Films Deposited by Ultrasonic Spray Pyrolysis. Applied Surface Science.

Kim, S., Yoon, H., Kim, D.Y., Kim, S.O., Leem, J.Y., (2013). Optical Properties and Electrical Resistivity of Boron-Doped $\mathrm{ZnO}$ Thin Films Grown by Sol-Gel Dip-Coating Method. Journal Optical Materials: 621-749.

Purwaningsih,S.Y.,Karyono.,Sudjatmoko.,(2005) . Efek Doping Al Pada Sifat Optik dan Listrik Lapisan Tipis $\mathrm{ZnO}$ Hasil Deposisi Dengan DC Sputtering. Jurnal Fisika dan Aplikasinya. Vol.1(1).

Rahman, M.Y.A., Roza, L., Umar, A.A., Salleh, M.M., (2016). Effect of Boric Acid Composition on The Properties of $\mathrm{ZnO}$ Thin Film Nanotubes and the Performance of Dye-Sensitized Solar Cell (DSSC). Journal of Alloys and Compounds. $648: 86-91$

Rahman, M.Y.A., Roza, L., Umar, A.A., Salleh, M.M., (2016). Effect of Dimethyl Borate Composition on The Performance of Boron Doped Zno Dye-Sensitized Solar Cell (DSSC). J.Mater Sci: Mater Electron. (27) : 2228-2234. 
Wen, B., Liu, C.Q., Wang, N., Wang, H.L., Liu, S.M., Jiang, W.W., Ding, W.Y., Fei, W.D., Chai, W.P., (2016). Crystallization Behavior and Properties of B-Doped $\mathrm{ZnO}$ Thin Films Prepared by Sol-Gel Method with Different Pyrolysis Temperatures. Chinese Journal of Chemical Physics. Vol.29(2).

Wen, B., Liu, C.Q., Wang, N., Wang, H.L., Liu, S.M., Ren, Y.H., Chai, W.P., (2017). Properties of Transparent Conductive Boron-Doped Zno Thin Films Deposited by Pulsed DC Magnetron Sputtering From Zn1- xBXO Targets. Applied Physics A Materials Science \& Processing. Vol 123.(211).

Winarti, S., Sarofa, U., Anggrahini, D., (2008).Ekstraksi dan Stabilitas Warna Ubi Jalar Ungu (Ipomoea batatas L.,) sebagai Pewarna Alami. Jurnal Teknik Kimia. Vol.3(1).

Yi Lee, S., Lan, W.H., Chao, W.M., Tsai, C.W., Shih, M.C., Wu, Y.D., Chou,Y.C., Hsu, Y.T., (2012). Boron-Doped Zinc Oxide Thin Films Fabricated by Ultrasonic Spray Pyrolysis. Opto-Electronics and Communications Conference (OECC 2012) Technical Digest :665-666 